\title{
PENINGKATAN LITERASI DATA MENUJU INDONESIA 4.0
}

\author{
Setia Pramana \\ Komputasi Statistik, Politeknik Statistika STIS, email :setia.pramana@stis.ac.id
}

\begin{abstract}
The Indonesian government has set 10 national priorities to face the Industrial Revolution 4.0 which is accompanied by an integrated roadmap known as Making Indonesia 4.0. Achieving these targets requires collaboration among the stakeholders (government institutions, associations and industry players, and academics). One of the key determinants of competitiveness in the Industry 4.0 era, is human capital including data literacy capability to analyze data generated from various technological devices becomes an information and policy, especially for the government.Politeknik Statistika STIS lecturers have held a series of activities to increase data literacy and big data technology for central and local governments, industry players, research institutions and universities. The activities were carried out in the form of a series of seminars, as well as workshops attended by decision makers of central and local governments, researchers and lecturers from various universities in Indonesia. As a result of this series of activities, the participants not only had an understanding of the importance of the data but were also able to use data to improve their evidence-based policies.
\end{abstract}

Keywords: data literacy, evidence-based policy, big data, industry 4.0

\section{PENDAHULUAN}

Perkembangan teknologi digital yang menjadi pionir revolusi industri ke empat telah berdampak sangat besar terhadap perubahan dalam bidang ekonomi, politik, bahkan militer dan budaya.

Revolusi Industri 4.0 yang pertama kali digunakan di publik dalam pameran industri Hannover Messe di kota Hannover, Jerman di tahun 2011 mencakup cyber-fisik, internet of things (IoT), komputasi awan (cloud computing), komputasi kognitif dan kecerdasan buatan (artificial intelligent). Revolusi industri 4.0 akan dan telah membawa banyak perubahan fundamental mengenai cara hidup, bekerja dan berhubungan satu sama lain dengan segala konsekuensinya.

Pada Industri 4.0 setiap kegiatan industri akan semakin efisien sehingga kebutuhan sumber daya manusia akan berkurang karena digantikan oleh mesin atau robot. Hal ini akan menyebabkan jutaan pekerjaan lama menghilang, dan jutaan pekerjaan jenis baru yang akan muncul.

Menurut Jobs Lost, Jobs Gained: Workforce Transitions in a Time of Automation yang dirilis McKinsey Global Institute (Desember 2017) pada 2030 sebanyak 400 juta sampai 800 juta orang harus mencari pekerjaan baru, karena digantikan mesin. Sedangkan untuk Indonesia menurut
McKinsey \& Co diperkirakan akan kehilangan 50 juta peluang kerja.

Pada industri 4.0, teknologi manufaktur sudah masuk pada tren otomatisasi dan pertukaran data, sehingga saat ini dibutuhkan kombinasi berbagai kemampuan (skills) terutama dalam kemampuan untuk membaca, analisis, dan menggunakan informasi (big data) di dunia digital.

Kemampuan untuk memanfaatkan, mengolah dan mendapatkan informasi dari data yang kompleks atau yang disebut literasi data menjadi salah satu bagian penting baik bagi masyarakat, industri maupun pemangku kebijakan.

Pemerintah Indonesia melalui Kementerian Perindustrian telah merancang peta jalan (roadmap) Making Indonesia 4.0 dalam mengimplementasikan sejumlah strategi dalam memasuki era industri 4.0. Beberapa langkah telah dilaksanakan untuk melibatkan beberapa pemangku kepentingan (stakeholder), mulai dari institusi pemerintahan, asosiasi dan pelaku industri, hingga unsur akademisi.

Pusat Penelitian dan Pengabdian Masyarakat (PPPM) Politeknik Statistika STIS (dahulu Sekolah Tinggi Ilmu Statistik) telah melakukan kegiatan untuk peningkatan literasi data, baik untuk industri, akademisi maupun pemerintah pusat dan daerah di seluruh Indonesia. Artikel ini akan membahas 
perencanaan, serta laporan berbagai kegiatan literasi data yang dilakukan selama empat tahun terakhir.

\section{PEMBAHASAN}

Sebagai salah satu kegiatan pengabdian kepada masyarakat, PPPM Politeknik Statistika STIS melakukan kegiatan literasi data dalam berbagai bentuk seperti workshop, training, maupun seminar dan dengan subtopik yang berbeda-beda kepada berbagai lembaga akademisi maupun pemerintahan.

Sejak tahun 2016 telah dilakukan 61 kegiatan PKM literasi data yang mencakup wilayah di 19 provinsi di Indonesia yang diadakan oleh Politeknik Statistika STIS dan dilaksanakan oleh para dosen. Selain dari kegiatan yang diadakan oleh kampus, para dosen dapat melakukan kegiatan pengabdian secara mandiri dengan berbagai bentuk, seperti seminar, serta workshop ke berbagai instansi.

Artikel ini fokus membahas rangkaian kegiatan pengabdian kepada masyarakat yang dilakukan oleh peneliti, dalam kurun waktu 2016 hingga 2019.

\section{Strategi}

Untuk melakukan peningkatan literasi data pada berbagai kalangan yang beragam memerlukan strategi khusus mengingat pengetahuan akan pentingnya data pada masyarakat masih sangat kurang. Berikut ini secara umum strategi yang dilakukan:

1. Data Awareness. Kegiatan ini merupakan langkah awal pada setiap jenis stakeholder. Penjelasan mengenai pentingnya data, jenis data yang tersedia baik bagi pemerintahan, universitas, lembaga riset maupun industri menjadi langkah awal yang sangat krusial. Diharapkan para pembuat kebijakan dapat menggunakan data dalam setiap kebijakan yang dibuat (Evidence Based Policy). Pada era digital saat ini sumber data yang tidak hanya berasal dari lembaga pemerintah seperti BPS, tapi juga dari dunia industri. Berbagai macam tipe data (variety), baik yang terstruktur maupun tidak dan juga kecepatan dihasilkannya (velocity) menjadi tantangan dan sekaligus peluang dalam persaingan di era serba cepat saat ini.

2. Data Analytics Mentoring. Langkah berikutnya setelah masyarakat sadar mengenai pentingnya data dalam segala macam kebijakan adalah memberikan dasar-dasar analisis data baik dari visualisasi, eksplorasi hingga interpretasi. Materi yang diberikan dalam bentuk buku dan modul yang spesifik sesuai dengan kebutuhan yang ada.

3. Pengikutsertaan (involvement). Mentoring merupakan pemberian dasar sains data yang selanjutnya perlu diimplementasikan pada data real yang disesuaikan dengan core bussines dari setiap institusi. Setiap grup peserta diberikan kasus yang mereka harus selesaikan. Hasilnya di buat dalam bentuk laporan yang akan dipresentasikan serta dipertahankan.

4. Coaching. Setiap satuan kerja atau divisi pasti memiliki business case yang berbeda dan spesifik. Langkah berikutnya adalah melakukan pendampingan (coaching) dari setiap kegiatan analisis data pada setiap institusi datau divisi, dimana peserta berasal. Hal ini dilakukan agar memastikan bahwa program ini telah berhasil.

\section{Peserta}

Cakupan peserta kegiatan sangat luas, dari mulai akademisi baik mahasiswa maupun dosen, pemerintah pusat dan daerah, berbagai Kementrian dan Lembaga. Gambar 1 memperlihatkan salah satu kegiatan yang diberikan bagi mahasiswa dan dosen.

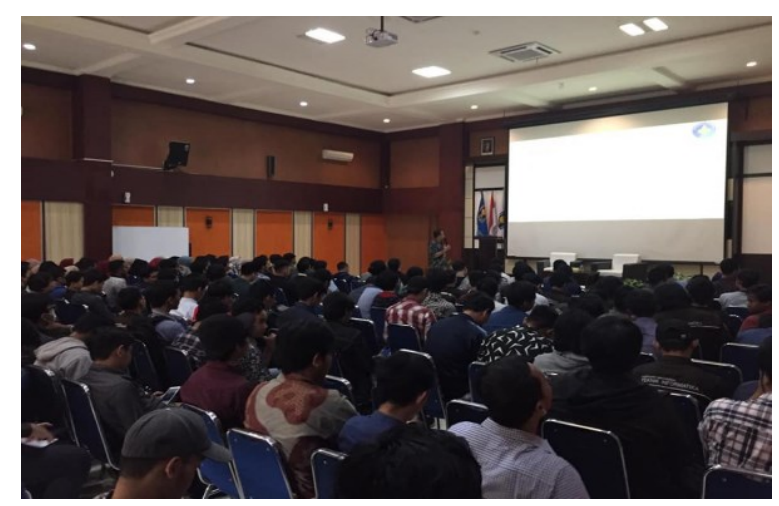

Gambar 1. Kegiatan literasi data di Universitas Islam Indonesia

Selain akademisi dan peneliti, sasaran kegiatan ini adalah para pejabat, serta pegawai pemerintah pusat maupun pemerintah daerah, organisasi perangkat daerah (OPD), serta Kementerian dan Lembaga (K/L). Gambar 2 memperlihatkan salah satu kegiatan bagi pemerintah pusat $(\mathrm{K} / \mathrm{L})$. 


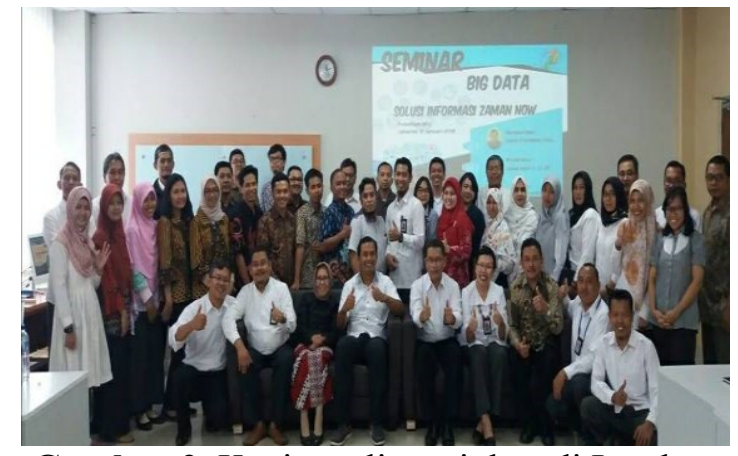

Gambar 2. Kegiatan literasi data di Lembaga Pemerintah

\section{Bentuk Kegiatan}

Kegiatan yang dilakukan tidak hanya dalam bentuk ceramah atau seminar, namun dalam bentuk hands-on training, serta workshop dan coaching. Hal ini dilakukan sesuai dengan kebutuhan serta situasi peserta.

Selain itu media ajar serta proses pengajaran yang gunakan selain slide yang ditampilkan saat tatap muka, kegiatan ini juga menggunakan media sosial serta youtube untuk penyebaran yang lebih luas dan efektif.

Berikut ini beberapa video (Gambar 3) yang telah dibuat yang tersedia untuk umum pada channel youtube:

a. Apakah Ilmu Statistika itu?

https://youtu.be/pBgwDTKz2wc

b. Apakah Data Scientist itu?

https://youtu.be/shlMyupSzdc

c. Tantangan sebagai Data Scientist

https://youtu.be/1Q-JBC-QBoY

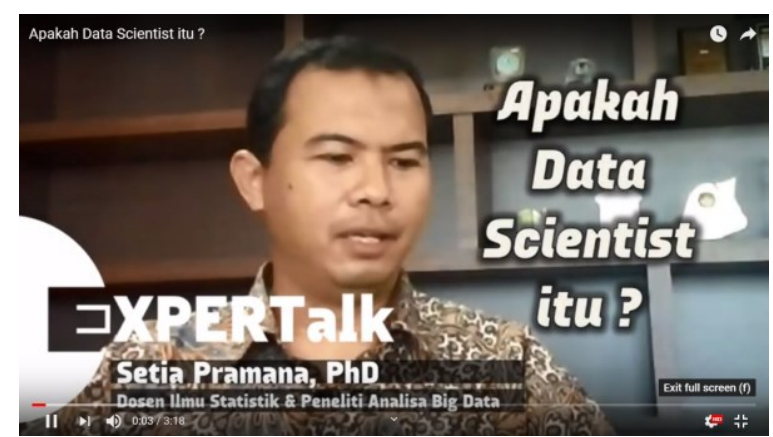

Gambar 3. Penjelasan mengenai sains data di Channel Youtube

\section{Topik Literasi Data}

Materi yang diberikan untuk meningkatkan Literasi data mencakup banyak hal sebagai berikut:

\section{Tingkat Awam}

a. Dasar-dasar mengenai data. Berbagai data yang tersedia untuk pemerintahan (official statistics), industri maupun akademisi. Berbagai sumber serta tipe data serta penggunaannya di berbagai bidang (Irawan dkk 2016).

b. Dasar visualisasi, eksplorasi, tabulasi serta pelaporan data. (Pramana dkk, 2016).

c. Berbagai sumber data baru di dunia digital (Big Data) seperti sosial media, IoT dan ecommerce. (Pramana dkk, 2017)

\section{Tingkat Menengah}

a. Penggunaan software untuk analisa data, baik Ms, Excel maupun Software khusus Statistika seperti R dan SPSS.

b. Pemrograman Statistika. (Pramana dkk 2017)

c. Overview mengenai Sains Data.

\section{Tingkat Lanjut:}

a. Big Data and Technology yang digunakan.

b. Advanced Analytics (Data mining, AI).

\section{KESIMPULAN}

Dari seluruh kegiatan yang dilakukan dapat terlihat bahwa data awareness masih relatif kecil terutama mengenai keuntungan penggunaan data, ketersedian data (statistik umum maupun sektoral) maupun metode analisanya. Para peserta mampu mengetahui dan mengerti proses dasar pengambilan, pengolahan, visualisasi, eksplorasi dan analisa data yang dilanjutkan dengan diseminasi data dalam bentuk laporan dan presentasi.

Terlihat animo para peserta untuk aktif dalam memenuhi kebutuan tenaga kerja ilmuan data saat ini.

\section{Tantangan}

Latar belakang pendidikan dari peserta yang sangat beragam yang membuat pengetahuan mengenai data juga beragam. Kebutuhan akan berbagai jenis data serta penerapanannya yang berbeda pada setiap stake holder. Adopsi teknologi yang berbeda antar daerah menyebabkan setiap daerah perlu strategi berbeda dalam mengenalkan literasi data

\section{Follow $U p$}

Hingga saat ini beberapa group coaching masih sedang dilakukan yang disesuaikan dengan kebutuhan pemangku kepentingan. Kedepannya akan dibuat platform e-learning khusus untuk literasi data serta literasi 
teknologi untuk peningkatan kualitas dan jangkauan kegiatan literasi data ini.

\section{REFERENSI}

Irawan, P.G., Usman, H., Berliana, S., Wicaksono, F. 2016. Official Statistics Sosial-Kependudukan Dasar. 2016. InMedia.

McKinsey Global Institute. 2017. Jobs Lost, Jobs Gained: Workforce Transitions in a Time of Automation, yang dirilis McKinsey Global Institute. https://www.mckinsey.com/featuredinsights/future-of-work/jobs-lost-jobsgained-what-the-future-of-work-will- mean-for-jobs-skills-and-wages. diakses Juli 2019.

Pramana, S. Yuniarto. B. Mariyah S., Santoso I., Nooraeni, R. 2018. Data Mining dengan $R$ Konsep dan Aplikasi. InMedia

Pramana. S, R Kurniawan, J Lee, Amin. I, dkk. 2017. Big Data for Government Policy: Potential Implementations of BigData for Official Statistics in Indonesia. Proceeding of 2017 International Workshop on Big Data and Information Security (IWBIS), Jakarta.

Pramana S., Yordani., R., Kurniawan R., Yuniarto B. 2017. Dasar-dasar Statistika dengan Software R: Konsep dan Aplikasi edisi 2. In Media 